\title{
Editorial
}

\section{Uma década de publicação}

Manter-se por dez anos com periodicidade constante de publicação e ser um espaço para a Psicologia Escolar e Educacional no Brasil foram as metas propostas em 1996 para a revista. Essas metas vêm sendo perseguidas com determinação e realizadas com qualidade. Sua publicação foi trimestral até 1999 e passou a semestral em 2000, contando com 20 fascículos impressos até 2005.

Inicialmente, a revista era distribuída aos sócios da Associação Brasileira de Psicologia Escolar e Educacional e encaminhada às bibliotecas de referência (Instituto de Psicologia da Universidade de São Paulo e Pontifícia Universidade Católica de Campinas) para indexação e catalogação. Atualmente, é enviada também a todas as bibliotecas brasileiras vinculadas a cursos de Psicologia, Sistema Conselhos e outras revistas com as quais mantém permuta, tanto no Brasil quanto no exterior.

Ao lado disso, está disponível no PePsic (http://scielo.bvs-psi.org.br/scielo.php) - base de dados eletrônica de Psicologia - e na página da ABRAPEE (www.abrapee.psc.br) com acesso aberto a seus fascículos desde 2000. Durante este ano estão sendo recuperados os arquivos anteriores, desde 1996, para digitalização e inserção nas bases de dados citadas, dando assim ampla visibilidade e acesso às publicações.

Essas conquistas são frutos de dedicação e competência ímpares da Profa. Dra. Geraldina Porto Witter e da Profa. Dra. Acácia Aparecida Angeli dos Santos, editoras desse periódico de 1996 a 1999 e de 2000 a 2003 , respectivamente, que agregaram renomados profissionais e pesquisadores brasileiros e internacionais à equipe de trabalho como pareceristas, e contaram com o apoio e incentivo das diretorias da ABRAPEE no período. Assim, a revista atingiu padrões de excelência nas publicações que culminaram com a avaliação Qualis Nacional $A$. $O$ apoio editorial do Conselho Nacional de Desenvolvimento Tecnológico - CNPq, desde 2002, também é de reconhecida importância. Como consequência, foi notório o aumento do fluxo de artigos provenientes de todos os estados brasileiros, garantindo e ratificando o caráter nacional do periódico. Constata-se também sua abrangência e visibilidade pela comunidade científica e profissional, não apenas da Psicologia, mas também de outras áreas correlatas.

Tem sido para mim, editora desde 2004, por um lado, editar a revista uma tarefa de continuidade frente à qualidade e relevância já conquistadas e, por outro, um desafio para manter, implementar e inovar o periódico. Isto posto, visando atender às demandas e transformações inerentes à própria Psicologia, bem como às procedentes das transformações sociais, culturais e tecnológicas da sociedade científica deste século. É importante destacar que conto hoje com a experiência não somente das editoras anteriores, mas também dos pareceristas, que são colaboradores há dez anos como membros do Corpo Editorial - Eunice Soriano de Alencar (Universidade Católica de Brasília), Leandro de Almeida (Universidade do Minho, Portugal), Solange Múglia Weschler (Pontifícia Universidade Católica de Campinas) e Thomas Okland (Florida University). Eles são minha referência e meu apoio a cada fascículo, em parceria com os atuais membros da comissão editorial, conselho editorial e apoio administrativo.

É um grande privilégio poder estar a frente desse periódico ao completar seus dez anos de existência, principalmente por ter se tornado a referência da área e atingido assim seus propósitos quando de sua criação. Manter informada a comunidade sobre a produção científica ao publicar artigos de pesquisa inéditos, preservar a história da Psicologia Escolar ao deixar registrados documentos, relatos e depoimentos a cada fascículo e possibilitar a atualização desde os acadêmicos aos profissionais com resenhas de livros, notícias bibliográficas e informes sobre eventos continua sendo a meta a ser perseguida pela Psicologia Escolar e Educacional ainda por vários anos. Inovar no formato, na mídia, no número de manuscritos por fascículos e garantir a qualidade e visibilidade são nosso compromisso. 